\title{
Low- and High-Moisture Extrusion of Pulse Proteins as Plant-Based Meat Ingredients: A Review
}

\author{
Serap Vatansever, ${ }^{1}$ Mehmet C. Tulbek, ${ }^{2}$ and Mian N. Riaz ${ }^{3,4}$
}

\begin{abstract}
Plant-based meat alternatives have become a major staple in the North American marketplace due to changing consumer demands. The main drivers of this market segment are changing dietary patterns, increasing numbers of consumers pursuing vegetarian and flexitarian lifestyles, rising individual income in developing countries, and an increase in global awareness of environmental concerns. Pulse crops and pulse proteins present an outstanding nutritional value chain, along with superior techno-functionality that can meet the requirements of plant proteins for producing meat analogue ingredients. In addition, pulse crops can assist in reducing carbon footprint by fixing nitrogen during agricultural production rotations. Pulse proteins also offer alternative solutions for addressing gluten-free, low-allergen, and GMO-free meat alternatives in the global marketplace. Alternative pulse-based solutions with similar sensory and texture attributes may be used to substitute for meat ingredients in new product applications.
\end{abstract}

Global awareness of healthy lifestyles, increased protein intake, and rising income in developing countries have shifted eating habits toward following a well-balanced diet that consists of a complete combination of proteins, carbohydrates, lipids, and micronutrients (1). As the world population has been predicted to reach 9.5 billion by 2050 , the demand for animal proteins would significantly increase due to changing consumption patterns in Asian and Southeast Asian countries (2). However, increased demand for animal-based products and their higher consumption levels may have negative impacts on the nutritional health of consumers and the environmental health of the planet (2-4). Particularly, increased use of animal-based proteins may increase carbon footprint, water consumption, and contribute to increased greenhouse gas formation. Alternative vegetable-based proteins can be considered to reduce these negative impacts and help food manufacturers develop sustainable solutions (3).

Meat production has significantly increased in the United States, with 87,409 million pounds produced by November 2019 (8). The global demand for animal-based proteins has been rising as well and is expected to reach twice its current level by 2050 (2). However, the animal protein production industry may negatively affect a sustainable environment and human health.

\footnotetext{
1 Department of Plant Sciences, North Dakota State University, P.O. Box 6050, Fargo, ND 581086050, U.S.A.

2 AGT Foods R\&D Centre, Saskatoon, SK S7T 0G3, Canada.

${ }^{3}$ Department of Food Science and Technology, Texas A\&M University, College Station, TX 77843, U.S.A.

${ }^{4}$ Corresponding author. Dr. Mian Nadeem Riaz, Department of Food Science and Technology,

Texas A\&M University, College Station, TX 77843, U.S.A. E-mail: $\underline{\text { mnriaz@tamu.edu }}$

https://doi.org/10.1094/CFW-65-4-0038

(c) 2020 Cereals \& Grains Association
}

Additionally, the dietary restrictions of various cultures and high cost of animal-based proteins may limit the consumption of animal-based products (5). Thus, a new generation of North American consumers has recently started following a more sustainable and eco-friendly plant-based protein consumption pattern that 1) consumes low-cholesterol, low-fat, high-protein, and high-dietary fiber foods; 2) contributes to a sustainable food supply; 3 ) contributes to a reduction in pollution and ecological footprint; and 4) assists in the reduction of water consumption in the food production chain $(1,2,5-7)$. Scientists have been conducting research on alternative protein resources that can provide bio-functionality for enhanced nutritional profile and improved techno-functionality attributes (e.g., protein solubility, gelation, water-binding capacity) compared with animal-based proteins to provide sustainable and low-carbon footprint food solutions for this growing market segment $(3,7,9)$.

Over the last two decades, pulse crops such as beans, peas, lentils, and chickpeas have received significant interest due to their sustainability benefits, high nutritional values, and technofunctionalities for producing plant-based proteins (10-13). Pulse crops play a vital role in terms of their environmental and economic contributions by decreasing the use of synthetic fertilizers by fixing nitrogen and, thus, reducing greenhouse gas emissions (14). In addition, pulse crops can provide solutions for the gluten-free industry as vegetable-based ingredients (e.g., flour, protein, starch, and fiber) that can present economic, sustainable, and nutritional benefits compared with animal-based proteins $(10,12-14)$.

In this article, we discuss the nutritional attributes and technological capabilities of pulse proteins by focusing on pea, lentil, and faba bean proteins as new alternatives for plant-based meat analogue applications.

\section{Role of Pulse Proteins in Plant-Based Foods}

Plant-based proteins can be produced from plant resources using dry and wet separation technologies $(4,9,15)$. Plant-based proteins are utilized in the food industry for their techno-functionalities (e.g., solubility, gelation). In comparison to other plant-based proteins, soybean and pulse proteins are primarily used to replace and blend with animal muscle proteins for meat formulations $(1,16)$.

Soybean ingredients have a significant presence in the plant based-protein industry (3) due to their notable nutritional properties, bioavailability, and techno-functionalities, which enhance the textural characteristics of end products $(1,17)$. Soybean ingredients (e.g., soy grits, soy protein concentrates, and soy protein isolates) have been studied extensively to address the needs of the plant-based foods industry $(1,17,18)$. However, during the last two decades, consumers have shown significant interest in pulse proteins, including pea (Pisum sativum), lentil 
(Lens culinaris), and faba bean (Vicia faba). Pulse proteins can provide an alternative to soybean proteins as they are low in allergens, are non-GMO protein sources, and have similar amino acid attributes and digestibility scores compared with soybean proteins $(1,3,7,9,11,14,17,19)$. Furthermore, promising techno-functionality attributes (e.g., solubility, gelling, waterbinding, and texturizing properties) of pulse proteins can provide additional benefits in food formulation systems

$(1,3,5,9,10,20)$.

\section{Structural Composition and Physicochemical Properties of Pea, Lentil, and Faba Bean Proteins}

Pulses are versatile crops due to their notable compositions, which consist of high protein contents, complex carbohydrates (starch, nonstarch oligosaccharides, and dietary fiber), minerals, vitamins, and phytochemicals $(9,10,13,21,22)$. The high protein contents of peas (14-31\%), lentils (21-31\%), and faba beans (19-39\%) are regarded as important plant-protein sources and a good fit for value-added ingredients that meet human protein intake needs $(10,11,14,23,24)$. Pulse proteins (Table I) are composed of major storage proteins, including globulins (soluble in salt solutions) and albumins (soluble in water) and minor proteins such as prolamins (soluble in alcohol) and glutelins (soluble at dilute acid or base solution) $(10,11,12,14,23,24)$.

Pulse globulins are the primary storage proteins of pulse proteins, accounting for $70-80 \%$ of the seed proteins, and act as nutrient reservoirs during seed germinations for plant growth. Pulse globulins dissociate at different $\mathrm{pH}$ values with the effect of ionic strength $(11,12)$. Based on the sedimentation coefficients of pulse globulins, globulins are classified into two main fractions: legumin (11S) and vicilin (7S). Legumin and vicilin comprise primary globular proteins in pea, lentil, and faba bean, with a legumin/vicilin ratio of 1-3:1 (11,12,21,24-27), $10.5: 1(14,26)$, and 2:1, respectively $(23,24)$, and with the ratio a function of amino acid profile, surface charges, size, and extrinsic factors (e.g., processing, cultivar, and growing environment). Structural differences between globular proteins are important for the techno-functionality of pulse proteins, such as the higher gelation ability of pea vicilin compared with pea legumin $(11,21$, $25)$. In addition, pea globulins contain a minor fraction, convicilin (7S-8S) (11).

Legumin (11S) is a hexamer of $300-410 \mathrm{kDa}$ with six subunits $(\sim 60-65 \mathrm{kDa})$ consisting of acidic, $\alpha$-chain $(\sim 40 \mathrm{kDa})$, and basic, $\beta$-chain $(\sim 20 \mathrm{kDa})$, polypeptides that are covalently linked via disulfide bridges $(2,21,25)$ due to the presence of cysteine residues $(21,28)$. The hydrophilic $\alpha$-chains are located in the outside of the molecule, while hydrophobic $\beta$-chains are located in the interior of the molecule (11).

Vicilin (7S) is a trimer of $145-190 \mathrm{kDa}$ consisting of $50-70 \mathrm{kDa}$ subunits. Pea vicilin contains a trimer of $150 \mathrm{kDa}(3,11,25)$, while faba bean vicilin has a trimer of $158-163 \mathrm{kDa}(12,23)$. Pea convicilin (7S-8S) is also a trimeric protein of $180-210 \mathrm{kDa}$, includ- ing a $\sim 70-71 \mathrm{kDa}$ subunit $(3,11,25)$. The linkage of subunits $(\alpha, \beta$, and $\gamma$ ) of vicilin occurs through noncovalent hydrophobic bonding linkages due to the absence of sulfur-containing amino acids (SCAAs), such as methionine and cysteine $(12,21,25)$. Vicilin contains more heterogeneous polypeptides through the cleavage of major subunits into lower molecular weight fragments $(10,11,17-20,25-30$, and $30-36 \mathrm{kDa})$ than legumin $(3,12,25)$. In addition, its carbohydrate residues, through glycosylation of the $\gamma$-subunit, allow more hydrophilic surface than legumin $(11,21)$; this carbohydrate residue was also found in lentil legumins (26). Furthermore, vicilin is a more flexible globular protein than legumin due to its higher heterogeneity polypeptide content and results in better interfacial activity, which may assist with better gel formation (2). Convicilin in peas exhibits high similarity to vicilin, containing $80 \%$ amino acid sequence homology (uncleaved vicilin subunits). However, this fraction differs from vicilin by a charged $\mathrm{N}$-terminal extension, the lack of in vivo cleavage, and its cysteine content $(3,27)$.

Albumins $(2 \mathrm{~S}, 5-80 \mathrm{kDa}$ ) play a major role in metabolic reactions during seed germination due to the metabolic and enzymatic proteins (protease and amylase inhibitors and lectins). Albumins are also higher in lysine content $(11,12,21)$. Prolamins and glutelins, the main storage proteins of cereals and building blocks of wheat gluten through polymerization and disulfite bonding, are observed at lower quantities in pulse proteins $(2,5)$.

The similar amino acid profiles of pea, lentil, and faba bean proteins is regarded as well-balanced in contrast to cereal proteins. These pulse proteins are high in terms of lysine, leucine, and phenylalanine, which are essential amino acids, and relatively similar to soybean proteins. Specifically, pulse globulins are a good source of arginine, phenylalanine, leucine, and isoleucine, whereas pulse albumins are high in lysine, tryptophan, and threonine (29). However, pulse proteins are deficient in terms of SCAAs, with a range of 2.0 to $3.3 \mathrm{~g} / 16 \mathrm{~g}$ of $\mathrm{N}$ and tryptophan. Thus, pulse proteins can be considered complementary supplements to cereal proteins, which are low in lysine but high in SCAAs $(10,14,20,23,26)$. Albumins and glutelins are higher in SCAAs than globulins within the pulse protein classification $(12,23,26)$.

The secondary structure of pulse proteins has a considerable affect on their techno-functionalities. Pulse proteins mainly contain $\beta$-conformations, which are mostly $\beta$-sheets and also $\beta$-turns, and antiparallel $\beta$-sheets and contain relatively fewer $\alpha$-helices $(21,28)$. The higher proportion of $\beta$-structures, particularly $\beta$-sheets, provides better thermal stability in contrast to that of $\alpha$-helices. However, the higher content of $\beta$-sheets in pulse proteins, such as $30 \%$ in peas and $33 \%$ in lentils, causes a reduction in protein digestibility due to restricted access of proteolytic enzymes after aggregation at high temperature (12). A slight reduction in the secondary structure (i.e., $\beta$-sheets and $\alpha$-helices) of pea protein isolate extrudates produced by low-

Table I. Protein content and protein fractions of peas, lentils, and faba beans ${ }^{\mathrm{a}, \mathrm{b}}$

\begin{tabular}{lcccccc}
\hline Pulse Crop & Crude Protein (\%) & Globulins $^{c}$ (\%) & Albumins (\%) & Glutelins (\%) & Prolamins (\%) & References \\
\hline Pea & $14-31$ & $49-70$ & $15-25$ & 11 & $4-5$ & $9,10,11,27$ \\
Lentil & $21-31$ & $47-70$ & $16-26$ & $11-15$ & $3-4$ & $10,14,26$ \\
Faba bean & $19-39$ & $69-78$ & $18-22$ & $10-18$ & $3-4$ & $10,23,24$ \\
\hline
\end{tabular}

${ }^{\text {a }}$ Values given as a range summarize data from multiple authors.

${ }^{b}$ Percentage of crude protein expressed on a dry weight basis.

${ }^{\mathrm{c}}$ Protein fraction percentages are based on total seed protein weight. 
moisture extrusion has been reported through the use of different screw speeds (30). Overall, the changes in the protein composition of pulse proteins may lead to differences in nutritional value and techno-functionality $(11,30)$.

\section{Pulse Protein Ingredients for Texturized Pulse Proteins}

Pulse Protein Ingredients. Pulse seed proteins are separated using dry- or wet-fractionation technologies based on the desired protein content and functionality (9). Dry fractionation can yield pulse protein products containing 48-65\%, and these proteins can be classified as pulse protein concentrates, whereas wet fractionation is the conventional method used to produce pulse protein isolates with more than $75 \%$ protein, such as $90.1 \%$ pea protein isolate and $\sim 89.3-90.1 \%$ lentil protein isolate $(9,11,15,26,31-33)$.

Pulse Protein Concentrates. Pulse protein concentrates in the current food market are commonly used as alternatives to soybean proteins and are produced by dry fractionation from fine milling combined with air classification. In this method, pulse seed (mostly dehulled) is finely milled; larger starch granules ( $20 \mu \mathrm{m}$ for pea starch) embedded in the protein matrix, which is surrounded by a fiber-rich cell wall (Fig. 1), are liberated from protein-rich particles (1-3 $\mu \mathrm{m}$ for pea protein body) and fiber-rich particles $(15,33)$. Subsequently, the denser starch particles are separated from the lighter protein-rich particles through air classification.

Dry fractionation of pulse proteins has been used as a sustainable method of plant protein extraction due to reduced use of energy and water. In addition, pulse protein concentrates are clean label products that can be used to meet consumer demands (33). The dry-fractionation process is also suitable for legume crops due to the presence of large starch granules, along with rich protein contents compared with cereal grains $(9,34)$. Pea protein concentrate is composed of $48-58 \%$ protein, $5-10 \%$ starch, $2.5-3.0 \%$ fat, $2.7-5.0 \%$ ash, $17-18 \%$ nonstarch polysaccharides, $11-13 \%$ total dietary fiber, and $6-7 \% \alpha$-oligosaccharides (9).

Pulse Protein Isolates. Wet fractionation is used to separate the protein and starch fractions of pulse flour. Different methodologies include alkaline extraction with isoelectric precipitation (AE/IEP), alkaline extraction with ultrafiltration (AE/UF), salt extraction (SE), and micellization (21). The AE/IEP process is often applied for wet fractionation of dry peas to produce pulse protein isolate. In this method, a slurry of starch granules, which is the dispersion of pulse flour in water to suspend starch granules and dissolve proteins, is separated using hydrocyclone from the protein solution. Subsequently, the solubilized proteins are precipitated at the isoelectric point ( $\mathrm{pH}=4.6-4.8$ for pea), and the solubilized fibers are also separated from proteins. The

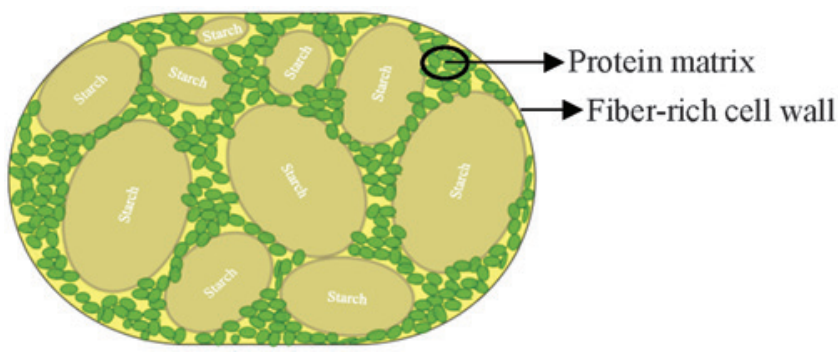

Fig. 1. Starches embedded in a protein matrix surrounded by a fiberrich cell wall. (Adapted from Schutyser et al. [33])
$\mathrm{pH}$ of precipitated proteins is adjusted to $\mathrm{pH} 7$ and dried to obtain a dry protein isolate with $75-90 \%$ protein $(26,33)$. The starch content $(\sim 0.4 \%)$ of this protein product is lower than that of pulse protein concentrate (35).

\section{Techno-functionality of Pulse Proteins for Texturized Pulse Proteins}

Functional properties of food proteins, as described by Kinsella (36), include physical and chemical properties that affect the functionalities of proteins in food systems during food preparation, processing, storage, and consumption. These characteristics affect the "quality" and sensory attributes of pulse proteins. Both intrinsic factors (e.g., size, shape, amino acid composition, structure, ratio between hydrophobicity and hydrophilicity, ratio between surface polar and nonpolar amino acids, and interactions among proteins, fats, carbohydrates, and other food compounds) and extrinsic factors (e.g., $\mathrm{pH}$, temperature, and salts) affect the functional properties of proteins $(26,36)$. It has been suggested that the important functional properties of pulse proteins for texturization are protein solubility, gelation, and water and oil absorption $(9,26)$.

Protein Solubility. Protein solubility might be defined as the equilibrium between protein-protein (hydrophobic) and protein-solvent (hydrophilic) interactions and can be retention of proteins in protein-solvent (e.g., protein-water) suspension after its centrifugation (21). Protein solubility is a primary functionality due to its close association with other functional attributes, such as emulsification, foaming, water-holding capacity (WHC), and gelation $(21,37,38)$. Good protein solubility is desired for these functional attributes and their protein-based formulations, such as protein gels employed in protein texturization for better protein-protein interaction and cross-linking $(37,38)$. Protein solubility depends on the balance of hydrophobic and hydrophilic amino acids, which are present mainly on the protein surface $(21,37)$. The surface properties of a protein, depending on the amount and distribution of its amino acids, influence protein behavior in a solution. The tendency of hydrophilic amino acid residues is toward the water interface, whereas the tendency of hydrophobic residues is toward the interior of proteins in water. These hydrophobic residues lead to the formation of surface hydrophobicity and subsequently hinder solubility (21). Additionally, $\mathrm{pH}$, ionic strength, ion composition, and interactions with other food components (e.g., lipids and carbohydrates) impact protein solubility in addition to processing applications (e.g., heating, freezing, and drying) (37).

The solubility of pulse proteins increases at $\mathrm{pH}$ values above and below the isoelectric point (pI), which is a zero-net charge, but is the lowest at $\mathrm{pI}$ between $\mathrm{pH} 4$ and 6 due to the fact there is no surface charge, leading to the formation of no electrostatic repulsive forces $(11,12,26,32)$. Thus, the solubility of pulse proteins exhibits a positive relationship with surface charge but a negative relationship with surface hydrophobicity (12). At pI, the lack of repulsive forces between the charged molecules cause protein-protein interactions, which result in protein aggregation and, subsequently, protein precipitation $(12,21)$. Based on surface hydrophobicity, depending on $\mathrm{pH}$ level, protein solubility varies. For instance, commercial pea protein isolate exhibits a low solubility ( 30\%) at $\mathrm{pH} 8$ (38) compared with its solubility $(\sim 70-95 \%)$ at $\mathrm{pH} 9$ (39). Similarly, faba bean and lentil protein isolates are highest at $\mathrm{pH} 8-9$ and lowest at $\mathrm{pH} 4-6(26,31)$.

Protein solubility varies based on ionic strength in addition to $\mathrm{pH}$ value (37). The salts in the solution may create a surrounding 
environment for proteins and, hence, decrease electrostatic repulsive forces, resulting in aggregates of protein due to hydrophobic interactions and other forces. After that, depending on the level of aggregation, protein precipitation takes place via the effect of salts. Some salts (e.g., hydrogen phosphate, sulfate, ammonium, and potassium salts) may lead to protein aggregation through promotion of ion-water interaction, whereas calcium salts may enhance the interactions between protein and water, leading to better solubility (21). In addition to ion strength, Lam et al. (21) reported that protein solubility decreases with protein denaturation, which allows protein-protein interaction through hydrophobic interactions.

Furthermore, different processing methods (e.g., AE/IEP, AE/ $\mathrm{UF}$, and SE) of protein isolation may lead to inconsistent protein solubility $(21,40)$. For instance, salt-extracted pea protein isolate has better protein solubility than pea protein isolates produced by AE/IEP and micellization. SE may enhance surface charge and decrease surface hydrophobicity of pea protein isolate, and consequently, create better solubility compared with other methods (29). The solubility of pea and lentil protein isolates produced using UF have superior solubility compared with those produced using IEP (40).

Gelation. Gelation of globular proteins is a key functionality of proteins in generating a three-dimensional network, which provides a structured network and enables the modification of textural and rheological properties of foodstuffs, such as soups, gels, and meat alternatives $(3,12,21,41)$. Gelation of globular proteins based on the heat-induced gelation mechanism consists of three stages: 1) employing a thermal process with native proteins (unfolded) to unfold buried residues in the protein interior and enhance protein-protein interactions; 2) aggregating buried residues through molecular interactions, noncovalent (hydrogen, ionic, and hydrophobic) interactions, and covalent disulfide linkage; and 3) forming a continuous threedimensional network via the arrangement of soluble protein aggregates that is stabilized by disulfide bridges and/or noncovalent bindings $(3,41,42)$.

The high functional performance of pulse proteins (i.e., pea, lentil, and faba bean) makes them a potential candidate for production of sustainable meat alternatives in the global food chain (19). The gelation ability of pulse protein is crucial to address this food production and replace soy counterparts in the market. Recent studies have shown that heat-induced pea protein gels are relatively weaker and less elastic than soybean protein gels under the same conditions due to the weaker interactions (i.e., protein-protein and protein-water interactions through disulfide bridges and noncovalent bindings) of pea proteins $(3,21,41)$.

Heat-induced gelation attributes of pea globular proteins may be related to the legumin/vicilin ratio (43). Sun and Arntfield (43) reported that a level of high legumin within legumin-vicilin mixtures caused a reduction in gel hardness. In contrast, O'Kane et al. (44) reported that the negative effect of pea legumins on pea protein isolate gelation was cultivar dependent. Furthermore, protein concentration, $\mathrm{pH}$, ionic strength, additives, and processing conditions of pulse proteins were found to be essential factors for gel formation. Lin et al. (16) showed that low protein concentration causes an inefficient protein-surface interaction. In contrast, a high concentration can result in poor dispersion, requiring extra energy input (e.g., mixing or shearing forces) to obtain sufficient dispersion of protein to generate a better network structure (16). The concentration promoting favorable gel formation by pea, lentil, and faba bean protein was reported to be in the range of 5.5 to $20 \%$ depending on processing method used and other conditions, such as ionic strength and $\mathrm{pH}$ values $(3,16,38,41,43,45,46,47)$. Boye et al. (40) showed that a strong gel was produced from lentil proteins (green and red lentil) extracted by IEP at a concentration of $12 \%$, whereas lentil proteins extracted by UF at concentrations of $8 \%$ (green lentil) and $10 \%$ (red lentil) showed strong gel formation. Zengh et al. (47) indicated that the higher protein concentration (15\%) of faba bean legumin led to gel formation in a shorter heating time than a $10 \%$ protein concentration.

Various approaches have been reported to improve the gelation properties of pulse proteins. Using transglutaminase to enhance the protein-protein interaction of pea protein isolate through cross-linking improved gel elasticity and stiffness of commercial pea protein isolate and provided results comparable to commercial soybean protein isolate and meat bologna in terms of gelation properties (48). The lower heating rate for gelation reduced the denaturation temperature of pea proteins, which is $78.5^{\circ} \mathrm{C}$, and promoted molecular rearrangements, where better protein aggregation occurs after protein unfolding (41). The addition of sodium chloride $(100 \mathrm{mM} \mathrm{NaCl})$ increased the thermal stability of pea proteins (3), raising the gelling temperature (21).

WHC and Oil-Holding Capacity of Pulse Proteins. WHC is defined as the amount of water that is absorbed per gram of protein and is the retention of water against gravity $(12,21,28)$. The WHC of proteins is critical for end-product quality in terms of mouthfeel, texture, and flavor retention. A higher WHC is essential to prevent losses in formulations such as meat alternatives during processing, helping to maintain an acceptable texture of end products $(5,12,21,28)$. Water binding by proteins occurs through various interactions (e.g., ion-dipole, dipole-dipole, and hydrostatic bindings) based on the amino acid composition of the protein. Highly charged amino acids tend toward water through electrostatic attraction (49).

The WHC of pulse proteins, which exhibits a positive correlation with protein solubility, changes based on $\mathrm{pH}$ values. Pulse proteins exhibit the lowest water retention at the pI due to significant protein-protein interactions through hydrophobic forces $(21,35)$. Studies have reported WHCs ranging from 1.9 to $4.8 \mathrm{~g} / \mathrm{g}$ for pea protein isolates produced using AE/IEP (28, 49,50 ). Osen et al. (35) reported WHCs ranging from 2.1 to $5.4 \mathrm{~mL} / \mathrm{g}$ for three commercial pea protein isolates.

WHC is essential in the texturization of plant-based proteins. Favorable water absorption of structured meat analogues has been determined as a minimum of three times their initial weight after cooking in boiling water for $15 \mathrm{~min}(5,18)$. Samard and Ryu (17) reported WHCs for soybean protein isolate and pea protein isolate meat analogues as 5.2 and 4.0 times their initial weight, respectively. The desired water absorptions of meat extenders produced with soybean flour and soybean protein concentrate were expected to be 2.5-3 times and 4.55 times their initial weight after exposure to water at room temperature for 5-15 min, respectively (18). Kim (19) showed that texturized faba bean protein concentrate produced with a highshear configuration and the addition of additives such as sodium bisulfite and pea protein isolate exhibited significantly higher WHCs than that of texturized soybean protein concentrate.

Oil-holding capacity (OHC) of proteins is described as the amount of fat absorbed per gram of protein (21). The interac- 
tion between proteins and lipids occurs between nonpolar side chains of proteins and the aliphatic chains of lipids through hydrophobic interactions $(21,50)$. OHC is a key functional property of proteins when they are used as a meat extender, meat replacer for meat-based food applications, and in baked goods to provide acceptable sensory attributes in end products (12). Shevkani et al. (28) reported that the fat absorption capacities of five pea protein isolates ranged between 5.5 and $7.2 \mathrm{~g} / \mathrm{g}$, whereas Osen et al. (35) recorded lower levels of fat absorption (1.3-1.7 mL/g) for three commercial pea protein isolates. Boye et al. (40) presented similar OHCs for pea and lentil proteins produced using AE/IEP but found different OHCs for them when they were extracted using AE/UF. The inconsistencies of OHCs for pulse proteins may be the result of different processing conditions and cultivar types (40).

\section{Texturized Pulse Proteins}

Texturized pulse proteins have been produced using low- and high-moisture extrusion processes to obtain meat alternatives (i.e., meat extenders and meat analogues) (Fig. 2). Meat alternatives have been utilized in the food industry to reduce the cost of meat-based formulations, as well as enhance their textural properties $(1,5)$. Recently, meat alternatives have drawn increasing interest in the meatless food industry.

The texturized protein industry is predominately associated with soy-based products due to their high bio- and technofunctionalities $(1,5,17,18)$. Riaz $(18)$ defined TVP (texturized vegetable protein) (1972) as "fabricated palatable food ingredients processed from an edible protein source including among other soy grits, soy protein isolate, and soy protein concentrates with or without suitable option ingredients added for nutritional or technological purposes." The U.S. Department of Agriculture (51) has also described texturized vegetable proteins as "food products made from edible protein sources and characterized by having structural integrity and identifiable structure such that each unit will withstand hydration and cooking, and other procedures used in preparing the food for consumption." Texturized vegetable proteins may be shaped in different forms (e.g., fibers, chunks, shreds, slices, and granules). When texturized vegetable proteins are hydrated and later cooked, retorted, or applied using other food procedures for consumption, they maintain their structural integrity and "chewy texture" (18). Texturized vegetable proteins are widely use in food systems to partially or entirely replace meat in the diet, while providing an appearance, texture, and nutrition profile that is comparable with meat products (18).

Texturized proteins may be produced using different plant proteins, such as pulse proteins (e.g., bean, pea, chickpea, lentil), cereal proteins (e.g., rice), and oilseed proteins (e.g., sunflower, flaxseed), as alternatives to highly allergenic soy-based ingredients and wheat proteins $(1,16,18)$. In the current market, pulse protein ingredients have become more attractive for use in texturization applications due to the high similarity of their bio- and techno-functionalities to soybean proteins $(17,35,40)$. In recent years, several studies revealed that meat extenders and meat analogues produced from pulse proteins (e.g., pea, lentil, and faba bean) may be more sustainable and have high potential in foodstuffs $(19,35)$.

\section{Extrusion Texturization of Vegetable Proteins}

Extrusion cooking of vegetable proteins has been defined as "the process in which moistened, expansile, starchy and/or proteinaceous materials are plasticized in a tube by a combination of moisture, pressure, heat, and mechanical shear. Extrusion cooking results in elevated product temperature within the tube along with gelatinization of starchy components, denaturation of proteins, stretching or restructuring of tactile components, and the exothermic expansion of the extrudate" (52). Extrusion cooking of proteinaceous materials (Fig. 3) has been extensively employed to provide the fibrous structure of protein material for various food applications. Application of mechanical and thermal energy during the extrusion process to proteinaceous materials leads to the transformation of native (folded) proteins to unfolded proteins with the loss of an organized structure. It results in the formation of a continuous and viscoelastic mass. In the extruder, this viscoelastic mass is aligned, cross-linked, reformed, and converted into an expandable structure that has a chewy texture $(18,53)$.

A typical extrusion system consists of a mixer (mixing raw materials), bin feeder (transferring uniformly raw material into preconditioner), preconditioner (preconditioning of raw material temperature and moisture through the injection of steam), extrusion barrel configuration, die, and knife. Extrusion cooking is a complex process due to its hydration, forming, cooking, unfolding, and alignment functions, in addition to providing the texturization of vegetable proteins through restructuring. During this process, proteins are extensively denatured in the presence of water and thermal energy $(18,54)$. The extrusion
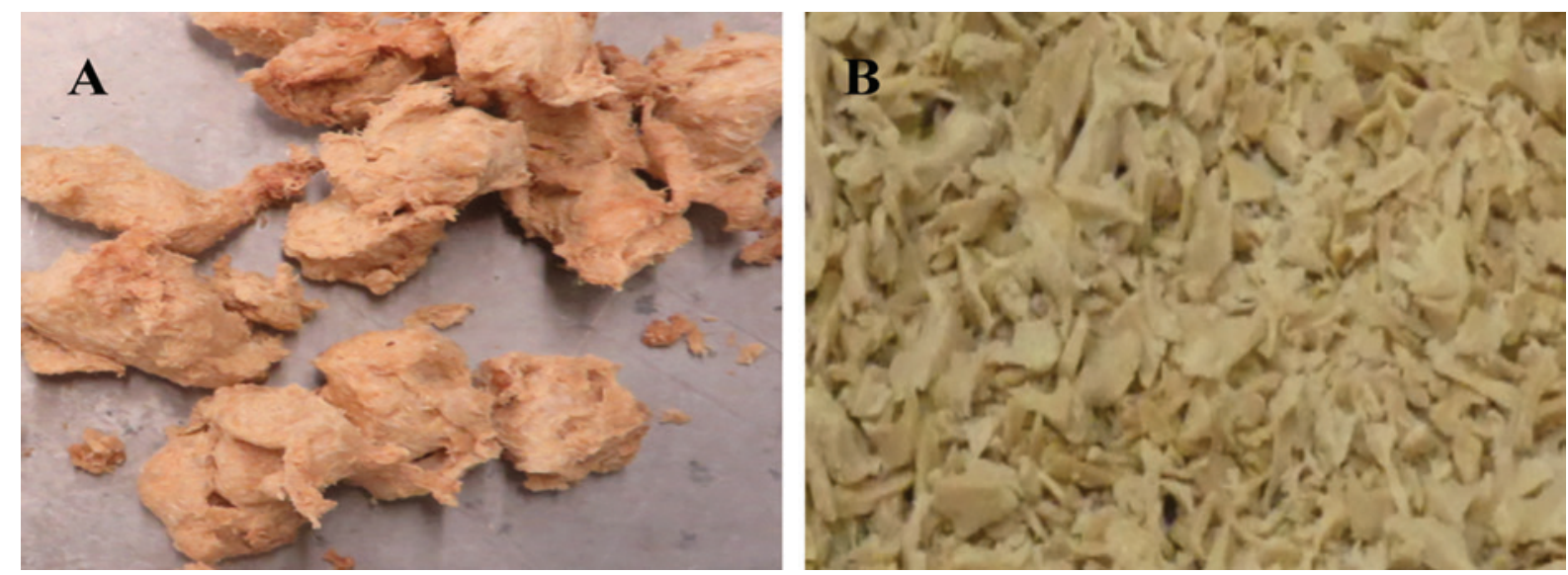

Fig. 2. Low-moisture (A) and high-moisture (B) pulse protein extrudates: A, texturized pea extender and B, pea meat analogue. 
cooking process reduces protein solubility due to protein aggregation but enhances protein digestibility through protein denaturation (18), which may reduce negatively correlated internal secondary $\beta$-conformations and external factors, such as protease inhibitors like trypsin and chymotrypsin inhibitors $(30,55)$. Furthermore, extrusion cooking reduces antinutrient proteins, such as lectins and hemagglutinins (54), and may reduce or remove undesirable aroma compounds, such as alcohols, aldehydes, and pyrazines that cause off-flavor in pulse ingredients (13). The use of a preconditioner may help to release off-flavor compounds. In general, ingredients used in processing integrate irreversibly and homogenously in a protein matrix. Thus, texturized proteins exhibit uniformity and integrity with major and minor ingredients through bonding dispersion and cross-linking and provides a convenient and transportable product $(18,56)$.

Preconditioning may be useful for materials with large particles (grit, flake) to provide uniform moisture along with elevated temperature. The mixing action in the preconditioner may be useful for releasing undesirable volatile compounds and destroying enzyme inhibitors in the presence of moisture (10$25 \%)$ and elevated temperatures $\left(65-100^{\circ} \mathrm{C}\right)$. In addition, other materials, such as flavors, coloring agents, and other additives, may be added in this stage to ensure uniform mixing with protein materials before introducing the raw materials to the extruder barrel. The preconditioning stage is helpful in obtaining a good laminar-structured texturized protein to prevent excessive expansion through uniform penetration of moisture, which leads to proper alignment of protein molecules, which improves the stability of the extruder and enhances finished product quality (57).

The extrusion barrel configuration is composed of various sections in which proteinaceous materials are structured (57). Briefly, the first barrel acts as a feeding zone, where the preconditioned protein material is transferred from the preconditioner into the extruder. After the first barrel, the protein material moves into the processing zone, where the amorphous protein material is converted into a colloidal dough with the addition of water, steam, and compression. The temperature of the highly moist proteinaceous dough begins to increase in a short time $(2-5 \mathrm{sec})$ due to mechanical energy generated by a rotating screw and steam injection. Extrusion cooking, such as lowmoisture cooking (15-30\%), generally occurs with a short retention time $(5-15 \mathrm{sec})$ and high temperature $\left(100-200^{\circ} \mathrm{C}\right)$. The moist dough is forced to flow along barrels through the screw(s) under high pressure and shear, which leads to vaporization of water and transformation of the dough into a viscoelastic, plasticized mass in the extruder barrels (57). Finally, the viscoelastic mass is pushed through the die openings. The mass moisture partially evaporates and rapidly expands to generate aerated, cellular structure in the finished product at the die when it is exposed to ambient pressures upon exiting the die $(58,59,60)$. The finished product is identified based on texture, crispiness, and density after cooling (59). The density of the extrudate is determined by adjusting the extrusion barrel temperature and moisture level (57).

\section{Types of Texturized Pulse Protein Products}

Texturized pulse protein products have been classified into various categories based on the purpose of the food application, such as high-protein snacks, meat extenders, and meat analogues (Fig. 4). Through the adjustment of operating parameters, the texture, appearance, and density of texturized pulse proteins can be varied (18). Texturized vegetable protein classifications based on Riaz (18) are listed as 1) high-protein snacks; 2) meat extenders (chunk and minced styles); 3 ) structured meat analogues (chunk and minced styles) with high moisture; and 4) textured meat proteins (a combination of vegetable protein and meat). This categorization system may be applicable for texturized pulse protein products due to the high similarity of pulse proteins to soybean proteins.

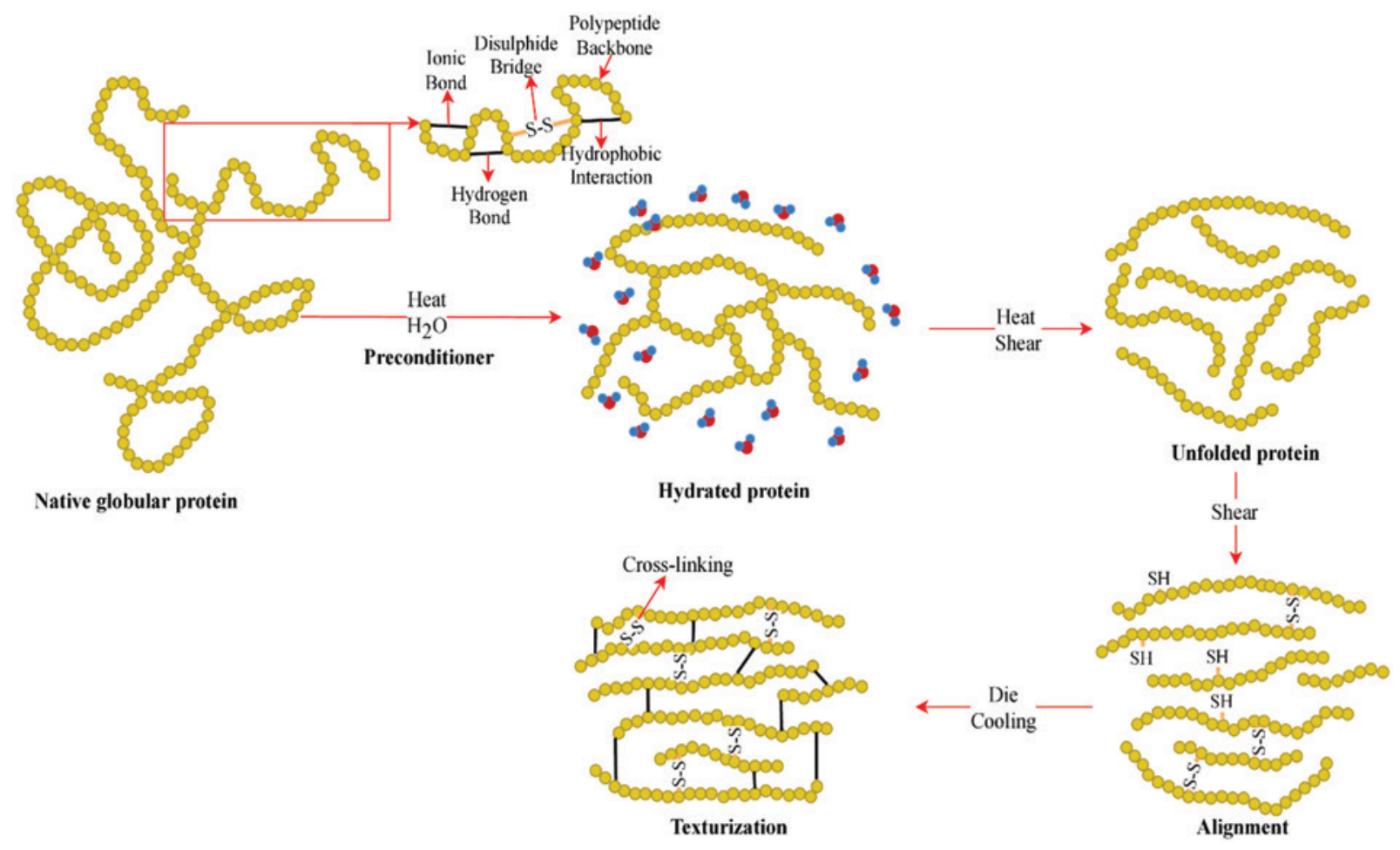

Fig. 3. Structural changes in pulse protein during extrusion cooking. 

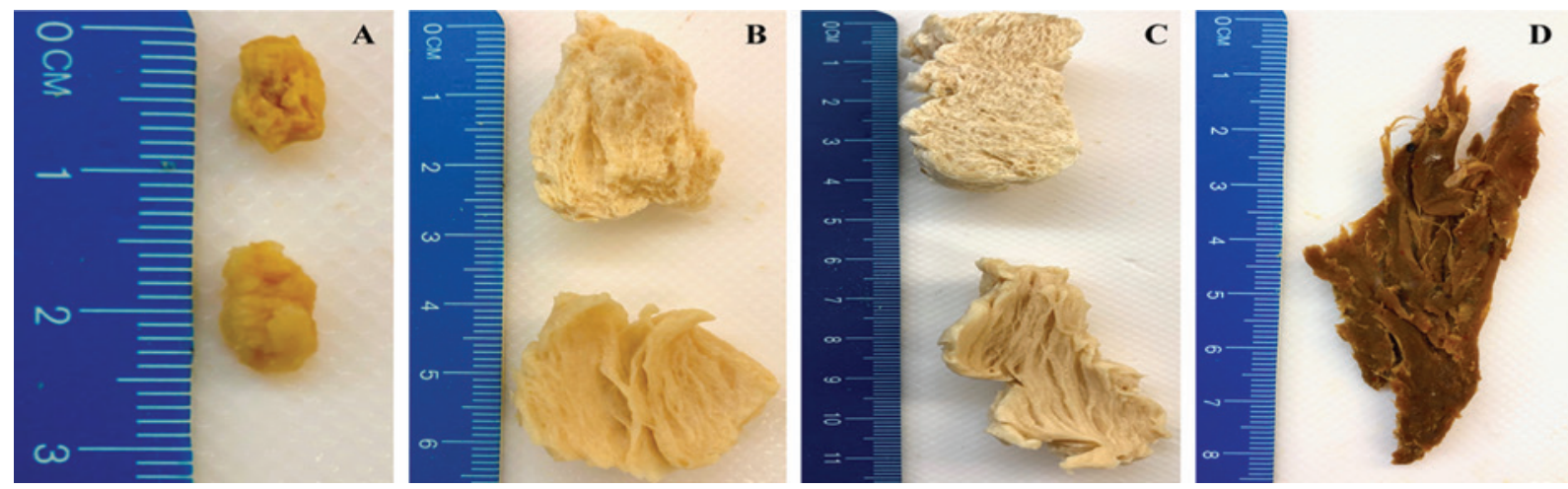

Fig. 4. Different forms of pea protein-based texturized proteins before and after hydration, except for the meat analogue (D): A, meat extender (granule); B, meat extender (nugget); C, meat extender (strip); and D, meat analogue (veggie jerky).

Table II. Texturized pulse proteins for different food applications

\begin{tabular}{|c|c|c|c|}
\hline Product $^{\mathrm{a}}$ & Raw Material & Processing Conditions & Reference \\
\hline PLPS $^{\mathrm{a}}$ & Yellow pea and red lentil flours & $\begin{array}{l}\text { High barrel temperatures }\left(150 \text { and } 175^{\circ} \mathrm{C}\right) \text {, with feed moisture content of } 20-24 \% \\
\text { and } 250 \mathrm{rpm} \text { screw speed, efficiently and completely transformed starch and } \\
\text { protein using nitrogen gas. }\end{array}$ & 62 \\
\hline PLPS & Yellow pea flour & $\begin{array}{l}\text { Constant die temperature }\left(150^{\circ} \mathrm{C}\right) \text {, with feed moisture }(14-18 \%) \text {, and die } \\
\text { pressure }(100,200,100,400,500 \mathrm{kPa}) \text {, produced pea-based snacks using } \\
\text { nitrogen gas. }\end{array}$ & 60 \\
\hline PLPS & $\begin{array}{l}\text { Pea protein isolate, pea fiber, and rice } \\
\text { starch }\end{array}$ & $\begin{array}{l}\text { Hight barrel end temperatures }\left(130^{\circ} \mathrm{C} \text { vs. } 170^{\circ} \mathrm{C}\right) \text {, including six zones }\left(30-130^{\circ} \mathrm{C}\right. \\
\left.\text { vs. } 30-150^{\circ} \mathrm{C}\right) \text {, with } 400-600 \mathrm{rpm} \text { screw speed and } 23-26 \% \text { moisture content, } \\
\text { produced expanded pea protein and fiber-enriched product with low-moisture } \\
\text { extrusion. }\end{array}$ & 61 \\
\hline PLPME & Pea protein concentrate & $\begin{array}{l}\text { Three temperature segments of eight barrel zones }\left(30-170^{\circ} \mathrm{C}\right) \text {, with } 135-245 \mathrm{rpm} \\
\text { screw speed and } 24-30.5 \% \text { moisture content, produced a product exhibiting } \\
\text { meat-like texture when hydrated. }\end{array}$ & 65 \\
\hline PLPME & Pea protein isolate & $\begin{array}{l}\text { Low-moisture extrusion with high barrel end temperatures }\left(130-170^{\circ} \mathrm{C}\right) \\
\text { including five zones }\left(30-170^{\circ} \mathrm{C}\right) \text {, with } 400-700 \mathrm{rpm} \text { screw speed and } 20-35 \% \\
\text { moisture content, produced expanded pea protein isolate. }\end{array}$ & 30 \\
\hline PLPME & $\begin{array}{l}\text { Pea, lentil, and faba bean protein } \\
\text { concentrates }\end{array}$ & $\begin{array}{l}\text { Pulse protein concentrates were extruded based on texturization of soy protein } \\
\text { concentrate ( } 75.8 \% \text { protein) after applying high-shear configuration and } \\
\text { addition of additives (calcium hydroxide, sodium bisulfide, xanthan gum, and } \\
\text { pea isolate). }\end{array}$ & 19 \\
\hline PLP-HMMA & Pea protein isolate & $\begin{array}{l}\text { Five barrel zones }\left(40-80^{\circ} \mathrm{C}\right) \text { with cooking temperatures }\left(100-160^{\circ} \mathrm{C}\right) \text {, including } \\
\text { cooling die }\left(100^{\circ} \mathrm{C}\right) \text {, with } 55 \% \text { moisture content and } 150 \mathrm{rpm} \text { screw speed, } \\
\text { produced nonexpanded product with fibrous whole-muscle structure. }\end{array}$ & 35 \\
\hline PLP-HMMA & $\begin{array}{l}\text { Pea, lentil, and faba bean protein } \\
\text { concentrates }\end{array}$ & $\begin{array}{l}\text { Pulse protein concentrates were extruded based on texturization of soy protein } \\
\text { concentrate ( } 75.8 \% \text { protein) after blending with additives (pea protein isolate, } \\
\text { wheat gluten, and canola oil). }\end{array}$ & 19 \\
\hline PLP-HMMA & $\begin{array}{l}\text { Pea protein isolate, soy protein isolate, } \\
\text { vital wheat gluten }\end{array}$ & $\begin{array}{l}\text { Barrel temperatures were established at } 100,160 \text {, and } 140^{\circ} \mathrm{C} \text { from feeding to die } \\
\text { zones, with } 50 \% \text { moisture content, } 250 \mathrm{rpm} \text { screw speed, and feed rate of } 100 \mathrm{~g} / \mathrm{min} \text {. }\end{array}$ & 17 \\
\hline
\end{tabular}

${ }^{a}$ PLPS: Pulse protein snack; PLPME: Pulse protein meat extender; PLP-HMMA: Pulse protein-high-moisture meat analogue.

Pulse Protein Snacks. Riaz (18) has defined high-protein snacks as a "dry form of textured protein for snacks and can be flavored externally using regional flavors." This crunchy and crispy product is produced mostly using soybean flour with $50-60 \%$ protein. It can also be made with soybean protein concentrate, with $70 \%$ protein and low protein solubility.

In the global food marketplace, pulse-based ingredients, mostly pea ingredients, have been used to produce pulse protein snacks. Efforts to address high consumer demand for healthier and more nutritious snacks have sparked renewed interest in extruded pea snacks $(30,60,61,62)$. There have been several studies published on expanded snacks using pulse protein ingredients (Table II) $(60,61,62)$. An expanded yellow pea snack using yellow pea flour (24\% protein) was successfully obtained by adjusting operating conditions (Table II) and using nitrogen gas as a blowing agent. The study demonstrated that different moisture levels and nitrogen gas impacted product expansion but did not influence the texture and color of the product. In addition, pulse proteins have been fortified with cereal ingredients for texturization (59). The expanded snack was produced with a combination of $50 \%(\mathrm{w} / \mathrm{w})$ pea starch, $40 \%(\mathrm{w} / \mathrm{w})$ oat fiber, and $10 \%(\mathrm{w} / \mathrm{w})$ pea protein isolate using a conventional twin-screw extruder with feed moisture (11.2-16\%), fixed barrel temperatures $\left(30,70,90\right.$, and $\left.135^{\circ} \mathrm{C}\right)$, die temperature $\left(145.9-160^{\circ} \mathrm{C}\right)$, fixed feeding rate $(0.68 \mathrm{~kg} / \mathrm{hr})$, fixed screw rotation $(200 \mathrm{rpm})$, and die opening $(3 \mathrm{~mm})$. In this study, acceptable sensory properties of an expanded pea product with high fiber ( $3.5 \mathrm{~g} /$ portion) and protein contents were produced at a moisture content of $11.2 \%$ and die temperature of $160^{\circ} \mathrm{C}$. Additionally, the authors stated that moisture was the most influential parameter on product quality (59). Pea ingredients are relatively new materials in the food industry compared with 

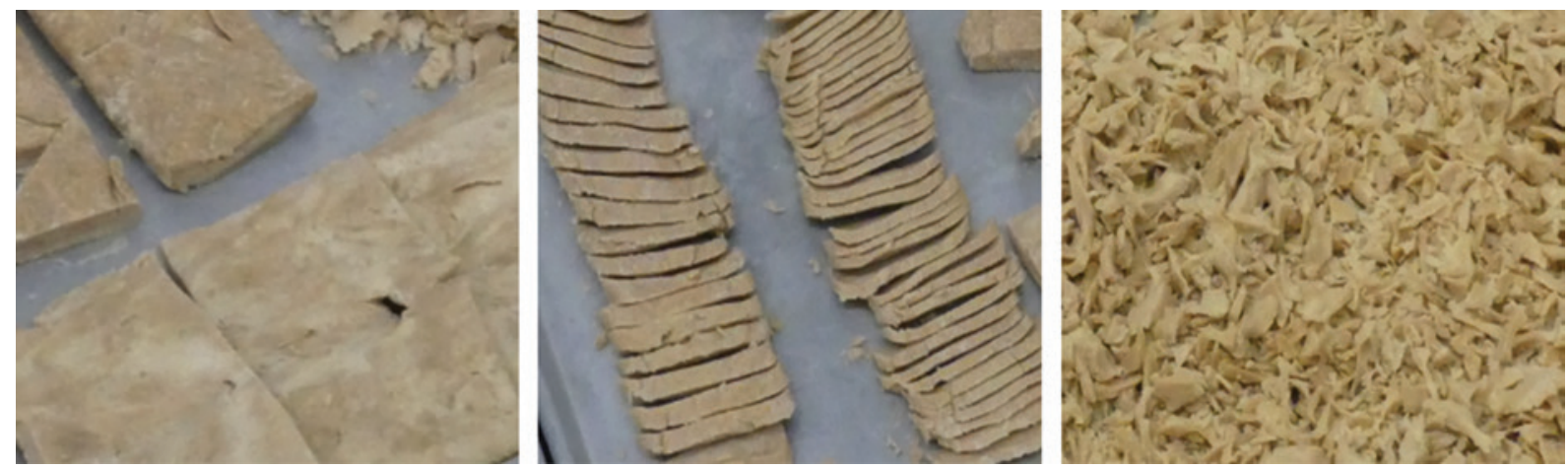

Fig. 5. Different forms of high-moisture meat analogues produced using pulse proteins.

soybean ingredients, but in recent years, there has been an increasing interest in pulse proteins for use in sustainable plantbased protein products $(59,60)$.

Pulse Protein Meat Extenders. Extruded meat extenders or alternatives are formulated with protein additives (63) and have been widely produced from defatted soybean flour and soybean concentrate using low-moisture extrusion processing with either a single- or twin-screw extruder (18). The purposes of this product are to incorporate a meat extender into a meat system 1) to enhance WHC and textural properties of meat products, such as burgers and sausages $(5) ; 2$ ) to provide a cost reduction for the final product (63); and 3) to address different diet trends, such as flexitarian (more plant-based foods), vegetarian, and vegan (2). For example, extruded meat extenders may be used to produce vegetarian meat alternatives by imitating ground beef or chicken breast to generate a meat formulation (e.g., sausage), using binders, soluble protein sources, and carbohydrate sources, such as starch and carboxymethylcellulose (18).

The spongy meat-like structure of meat extenders (Fig. 4), such as flake $(>2 \mathrm{~mm})$, minced $(>2 \mathrm{~mm})$, and chunk, with a size range of 15-20 mm, exhibits a chewy texture after hydrating in water (5). Meat extenders tend to retain 60-65\% moisture. After blending with meat or meat emulsions, they may retain $20-30 \%$ moisture in the end product due to their high WHC. The WHC of meat extenders varies depending on protein materials used. A typical meat extender produced from soybean flour (50\% protein) tends to absorb 2.5-3 times the water of its initial weight, while a meat extender produced from soybean concentrate (70\% protein) may absorb 4.5-5 times the water of its initial weight after hydrating for $15 \mathrm{~min}$ at room temperature $(18,64)$.

Pulse protein meat extenders have recently been evaluated (Table II) in several research studies using low-moisture extrusion. Pea protein concentrate and pea protein isolate were extruded with low moisture to produce meat alternatives. Lowmoisture extrusion of pea protein concentrate ( $55.4 \%$ protein) was successfully texturized and had a WHC that was comparable to soy-based extrudates (65). Low-moisture extrusion of pea protein isolate $(81.5 \%$ protein) was employed to provide a high-protein meat extender (30). Texturization of lentil protein concentrate (55.4\% protein) and faba bean protein concentrate (61.5\% protein) was recently performed to manufacture meat extenders after several modifications compared with soy-based extrudates and resulted in improved WHC of texturized faba bean protein concentrate (19).

High-Moisture Pulse Protein Meat Analogues. Meat analogues (Fig. 5) are texturized protein products that mimic meat, poultry, and fish in appearance, color, flavor, and texture (fibrous, layered structure) through texturization of vegetable proteins, including pea proteins, by extrusion cooking $(5,18)$. Meat analogues are distinctly different than meat extenders in terms of extrusion cooking. They are produced mostly under high-moisture conditions ( $>50 \%$ moisture) to reduce viscous dissipation, along with a long cooling die at the end of the extruder to prevent expansion, and can ultimately resemble the appearance and texture of fibrous whole-muscle structures (35).

High-moisture extrusion cooking with pulse proteins, such as pea protein isolate, is a relatively new trend in the food market that provides an alternative to highly allergenic soy- and wheatbased products, and limited studies have been conducted (17) (Table II). Osen et al. (35) showed that commercial pea protein isolates can be successfully employed to produce palatable wholemuscle meat alternatives and later revealed that the structural integrity of pea protein isolates during extrusion is mostly maintained through disulfide bonds and some noncovalent interactions (67). Kim (19) used pulse proteins along with additives (pea protein isolate, wheat gluten, and canola oil) to produce a pulse protein, high-moisture meat analogue and showed that these products have an appearance similar to a soy-based meat analogue but less texture. These authors noted that high-moisture extrusion of pulse proteins is applicable for alternative meat analogues. In a recent study, pea protein isolate and other plant proteins were texturized at $50 \%$ feed moisture to produce a meat analogue without a cooling die, and the extrudates were dried. The pea protein isolate meat analogue was the highest quality product compared with soy, wheat, and other extrudates (17).

The use of meat analogues with high similarity to the sensory quality of meat has been widely utilized for various meat product applications, such as hamburgers, steak, chicken, sausage, hot dogs, patties, Canadian bacon, sliced lunch meat, and stuffed turkey (5). Asgar et al. (5) indicated that the primary constraint of meat analogues in the current market is the substantial off-flavor issue and acceptable texture. Therefore, food technologists and researchers have been focusing on using deflavored pulse proteins and better techno-functionality for the texturizing process.

Texturized Meat Proteins. Texturized meat proteins are the extrudates produced from vegetable proteins along with meat to stimulate the texture of whole-muscle meat structures (18). These products may be applied to pet and human foods. Research studies based on these meat analogues are limited. In a recent study, insect protein concentrate was fortified with soybean protein concentrate from 15 to $40 \%$ to obtain a meat analogue using high-moisture extrusion. The authors found that 
high barrel temperature $\left(170^{\circ} \mathrm{C}\right)$ provided better hardness than cooking at $160^{\circ} \mathrm{C}$ and revealed that incorporation of insect protein concentrate into vegetable proteins may be a viable approach to obtain products with meat-like structures and comparable to $100 \%$ soy-based meat analogues (68).

\section{Future Trends and the Challenges of Meat Alternatives}

Increasing global meat consumption, a rapidly growing human population, and increasing average income in developing countries are generating additional demand for high-protein foods, which may create a protein gap in the future (2). Among the high-protein food solutions, animal-based proteins are being considered as a nonsustainable route due to environmental and health concerns, especially among millennial consumers (71). In addition, changes in eating habits, such as following flexitarian and vegetarian diets, have increased the attention on sustainable plant protein routes to replace animal-based proteins $(2,7,69)$. Over the last decade, meat alternatives produced using plant-based proteins have shown a sustainable, eco-friendly route to address increasing global demands for nutritious, healthy, and sustainable food solutions.

The global meat alternative market has shown significant growth, valued at US\$4.1billion in 2017, and is expected to reach US $\$ 8.1$ billion by $2026(70)$. Texturized proteins as a meat substitute accounted for the largest share of the total market revenue (35.8\%) in 2017. Currently, food companies have started to expand their innovation pipelines to address the needs of plant-based meat products using texturized proteins, including pulse proteins, for their formulations. Recently, The Good Food Institute has reported that $33 \%$ of the U.S. population consumes plant-based meat regularly. Also, 19\% of consumers are willing to spend more on plant-based meat than animal-based meat solutions. The consumer segment profile for this market tends to be millennials, highly educated, and urban (71). The rising market value of texturized proteins shows that interest in this market will remain, and pulse proteins will present new solutions for end users.

The major constraint for producing meat alternatives using pulse proteins is the sensory attributes of texturized proteins, specifically texture and flavor (69). Kumar et al. (69) reported that the primary challenge of researchers in developing meat alternatives is the sensory quality of meat due to differences resulting in the taxonomic factors of meat. Furthermore, these authors suggested that the classification of meat alternatives may be presented as nonmeat foods that possess sensory qualities that are highly similar to meat for processed meat products.

\section{Conclusions}

Pulse proteins have shown considerable growth in the global food market for the last two decades due to their low allergenicity and GMO-free attributes compared with other meat alternatives. Future research studies focusing on enhanced nutritional profiles and elevated protein digestibility-corrected amino acid scores (PDCAAS), improving flavor attributes through the removal of beany notes, and enhancing techno-functional profiles (e.g., high gelation properties of pulse proteins) will clarify the chemistry and processing capabilities of pulse proteins to address new and emerging applications.

\section{References}

1. Balestra, F., and Petracci, M. Technofunctional ingredients for meat products: Current challenges. Page 45 in: Sustainable Meat Production and Processing. Academic Press, Cambridge, MA, 2019.
2. Alves, A. C., and Tavares, G. M. Mixing animal and plant proteins: Is this a way to improve protein techno-functionalities? Food Hydrocoll. DOI: doi.org/10.1016/j.foodhyd.2019.06.016. 2019.

3. Mession, J.-L., Chihi, M. L., Sok, N., and Saurel, R. Effect of globular pea proteins fractionation on their heat induced aggregation and acid cold-set gelation. Food Hydrocoll. 46:233, 2015.

4. Pojic, M., Misan, A., and Tiwari, B. Eco-innovative technologies for extraction of proteins for human consumption from renewable protein sources of plant origin. Trends Food Sci. Technol. 75:93, 2018.

5. Asgar, M. A., Fazilah, A., Huda, N., Bhat, R., and Karim, A. A. Nonmeat protein alternatives as meat extenders and meat analogs. Compr. Rev. Food Sci. F 9:513, 2010.

6. Chao, D., and Aluko, R. E. Modification of the structural, emulsifying, and foaming properties of an isolated pea protein by thermal pretreatment. Cyta J. Food 16:357, 2018.

7. van der Weele, C., Feindt, P., van der Goot, A. J., van Mierlo, B., and van Boekel, M. Meat alternatives: An integrative comparison. Trends Food Sci. Technol. 88:505, 2019.

8. U.S. Department of Agriculture, Agriculture Research Service. Red meat and poultry production. Published online at www.ers.usda. gov/data-products/livestock-meat-domestic-data/livestock-meatdomestic-data/\#Red\%20meat\%20and\%20poultry\%20production. USDA ARS, Beltsville, MD, 2019.

9. Tulbek, M. C., Lam, R. S. H., Wang, Y., Asavajaru, P., and Lam, A. Pea: A sustainable vegetable protein crop. Page 145 in: Sustainable Protein Sources. Elsevier, Amsterdam, Netherlands, 2017.

10. Hall, C., Hillen, C., and, Robinson, J. G. Composition, nutritional value, and health benefits of pulses. Cereal Chem. 94:11, 2017.

11. Lu, Z. X., He, J. F., Zhang, Y. C., and Bing, D. J. Composition, physicochemical properties of pea protein and its application in functional foods. Crit. Rev. Food Sci. 37:1, 2019.

12. Shevkani, K., Singh, N., Chen, Y., Kaur, A., and Yu, L. Pulse proteins: Secondary structure, functionality and applications. J. Food Sci.Technol. Mys. 56:2787, 2019.

13. Vatansever, S., and Hall, C. Flavor modification of yellow pea flour using supercritical carbon dioxide plus ethanol extraction and response surface methodology. J. Supercrit. Fluid. DOI: 10.1016/j. supflu.2019.104659. 2020.

14. Khazaei, H., Subedi, M., Nickerson, M., Martinez-Villaluenga, C., Frias, J., and Vandenberg, A. Seed protein of lentils: Current status, progress, and food applications. Foods. DOI: 10.3390/foods8090391. 2019.

15. Pelgrom, P. J. M., Vissers, A. M., Boom, R. M., and Schutyser, M. A. I. Dry fractionation for production of functional pea protein concentrates. Food Res. Int. 53:232, 2013.

16. Lin, D. Q., Lu, W., Kelly, A. L., Zhang, L. T., Zheng, B. D., and Miao, $S$. Interactions of vegetable proteins with other polymers: Structure-function relationships and applications in the food industry. Trends Food Sci. Technol. 68:130, 2017.

17. Samard, S., and Ryu, G. H. Physicochemical and functional characteristics of plant protein-based meat analogs. J. Food Process Pres. DOI: doi.org/10.1111/jfpp.14123. 2019.

18. Riaz, M. N. Texturized vegetable proteins. Page 395 in: Handbook of Food Proteins. Woodhead Publishing Series in Food Science, Technology and Nutrition. Woodhead Publishing, Sawston, U.K., 2011.

19. Kim, T. Texturization of pulse proteins: Peas, lentils, and faba beans. Ph.D. dissertation. Published online at http://hdl.handle. net/1969.1/173522. Texas A\&M University, College Station, TX, 2018.

20. Kaiser, A. C., Barber, N., Manthey, F., and Hall, C. Physicochemical properties of hammer-milled yellow split pea (Pisum sativum L.). Cereal Chem. 96:313, 2019.

21. Lam, A. C. Y., Karaca, A. C., Tyler, R. T., and Nickerson, M. T. Pea protein isolates: Structure, extraction, and functionality. Food Rev. Int. 34:126, 2018.

22. Simons, C. W., Hall, C., and Vatansever, S. Production of resistant 
starch (RS3) from edible bean starches. J. Food Process. Pres. DOI: doi.org/10.1111/jfpp.13587. 2018.

23. Multari, S., Stewart, D., and Russell, W. R. Potential of fava bean as future protein supply to partially replace meat intake in the human diet. Compr. Rev. Food Sci. F 14:511, 2015.

24. Robinson, G. H. J., Balk, J., and Domoney, C. Improving pulse crops as a source of protein, starch and micronutrients. Nutr. Bull. 44:202, 2019.

25. Barac, M., Cabrilo, S., Pesic, M., Stanojevic, S., Zilic, S., Macej, O., and Ristic, N. Profile and functional properties of seed proteins from six pea (Pisum sativum) genotypes. Int. J. Mol. Sci. 11:4974, 2010.

26. Boye, J., Zare, F., and Pletch, A. Pulse proteins: Processing, characterization, functional properties and applications in food and feed. Food Res. Int. 43:414, 2010.

27. Tzitzikas, E. N., Vincken, J. P., De Groot, J., Gruppen, H., and Visser, R. G. F. Genetic variation in pea seed globulin composition. J. Agric. Food Chem. 54:425, 2006.

28. Shevkani, K., Singh, N., Kaur, A., and Rana, J. C. Structural and functional characterization of kidney bean and field pea protein isolates: A comparative study. Food Hydrocoll. 43:679, 2015.

29. Stone, A. K., Karalash, A., Tyler, R. T., Warkentin, T. D., and Nickerson, M. T. Functional attributes of pea protein isolates prepared using different extraction methods and cultivars. Food Res. Int. 76:31, 2015.

30. Beck, S. M., Knoerzer, K., and Arcot, J. Effect of low moisture extrusion on a pea protein isolate's expansion, solubility, molecular weight distribution and secondary structure as determined by Fourier transform infrared spectroscopy (FTIR). J. Food Eng. 214:166, 2017.

31. Aryee, A. N. A., and Boye, J. I. Comparative study of the effects of processing on the nutritional, physicochemical and functional properties of lentil. J. Food Process. Pres. DOI: doi.org/10.1111/ jfpp.12824. 2017.

32. Ettoumi, Y. L., and Chibane, M. Some physicochemical and functional properties of pea, chickpea and lentil whole flours. Int. Food Res. J. 22:987, 2015.

33. Schutyser, M. A. I., Pelgrom, P. J. M., van der Goot, A. J., and Boom, R. M. Dry fractionation for sustainable production of functional legume protein concentrates. Trends Food Sci. Technol. 45:327, 2015.

34. Simsek, S., Tulbek, M. C., Yao, Y., and Schatz, B. Starch characteristics of dry peas (Pisum sativum L.) grown in the USA. Food Chem. 115:832, 2009.

35. Osen, R., Toelstede, S., Wild, F., Eisner, P., and Schweiggert-Weisz, U. High moisture extrusion cooking of pea protein isolates: Raw material characteristics, extruder responses, and texture properties J. Food Eng. 127:67, 2014.

36. Kinsella, J. E. Relationships between structure and functional properties of food proteins. Page 51 in: Food Proteins. P. F. Fox and J. J. Condon, eds. Applied Science Publisher LTD, London, U.K., 1982.

37. Smith, D. M. Protein separation and characterization procedures. Page 275 in: Food Analysis. 4th ed. S. S. Nielsen, ed. Springer, NY, 2009.

38. Adebiyi, A. P., and Aluko, R. E. Functional properties of protein fractions obtained from commercial yellow field pea (Pisum sativum L.) seed protein isolate. Food Chem. 128:902, 2011.

39. Karaca, A. C., Low, N., and Nickerson, M. Emulsifying properties of chickpea, faba bean, lentil and pea proteins produced by isoelectric precipitation and salt extraction. Food Res. Int. 44:2742, 2011.

40. Boye, J. I., Aksay, S., Roufik, S., Ribereau, S., Mondor, M., Farnworth, E., and Rajamohamed, S. H. Comparison of the functional properties of pea, chickpea and lentil protein concentrates processed using ultrafiltration and isoelectric precipitation techniques. Food Res. Int. 43:537, 2010.

41. Mession, J. L., Sok, N., Assifaoui, A., and Saurel, R. Thermal denaturation of pea globulins (Pisum sativum L.) - Molecular interactions leading to heat-induced protein aggregation. J. Agric. Food
Chem. 61:1196, 2013.

42. Arntfield, S. D., and Murray, E. D. Heating rate effects thermalproperties and network formation for vicilin and ovalbumin at various $\mathrm{pH}$ values. J. Food Sci. 57:640, 1992.

43. Sun, X. D., and Arntfield, S. D. Gelation properties of salt-extracted pea protein induced by heat treatment. Food Res. Int. 43:509, 2010.

44. O'Kane, F. E., Vereijken, J. M., Gruppen, H., and van Boekel, M. Gelation behavior of protein isolates extracted from 5 cultivars of Pisum sativum L. J. Food Sci. 70:C132, 2005.

45. Bajaj, P. R., Bhunia, K., Kleiner, L., Joyner, H. S., Smith, D., Ganjyal, G., and Sablani, S. S. Improving functional properties of pea protein isolate for microencapsulation of flaxseed oil. J. Microencapsul. 34: 218,2017

46. Shand, P. J., Ya, H., Pietrasik, Z., and Wanasundara, P. Physicochemical and textural properties of heat-induced pea protein isolate gels. Food Chem. 102:1119, 2007.

47. Zheng, B. A., Matsumura, Y., and Mori, T. Thermal gelation mechanism of legumin from broad beans. J. Food Sci. 56:722, 1991.

48. Shand, P. J., Ya, H., Pietrasik, Z., and Wanasundara, P. Transglutaminase treatment of pea proteins: Effect on physicochemical and rheological properties of heat-induced protein gels. Food Chem. 107:692, 2008.

49. Stone, A. K., Avarmenko, N. A., Warkentin, T. D., and Nickerson, M. T. Functional properties of protein isolates from different pea cultivars. Food Sci. Biotechnol. 24:827, 2015.

50. Withana-Gamage, T. S., Wanasundara, J. P. D., Pietrasik, Z., and Shand, P. J. Physicochemical, thermal and functional characterisation of protein isolates from Kabuli and Desi chickpea (Cicer arietinum L.): A comparative study with soy (Glycine max) and pea (Pisum sativum L.). J. Sci. Food Agric. 91:1022, 2011.

51. U.S. Department of Agriculture, Agriculture Research Service. Textured vegetable protein products (B-1) to be used in combination with meat for use in lunches and suppers served under child feeding program. FNS Notice 219. USDA ARS, Beltsville, MD, 1971.

52. Smith, O. B. Textured vegetable proteins. Presented at the World Soybean Research Conference, University of Illinois, Aug. 3-8. 1975.

53. Harper, J. M. Extrusion texturization of foods. Food Technol. 40: 70, 1986.

54. Strahm, B. Raw material selection and additive effect on textured vegetable protein. In: Manual of Textured Vegetable Protein and Other Soy Products. M. Riaz and M. Barron, eds. Food Protein Research \& Development Center, Texas A\&M University, College Station, TX, 2002.

55. Joye, I. Protein digestibility of cereal products. Foods. DOI: doi. org/10.3390/foods8060199. 2019.

56. Rokey, G. J., Huber, G. R., and Ben-Gera, I. Extrusion-cooked and textured defatted soybean $\mathrm{fl}$ ours and protein concentrates. In: Proceedings of the World Conference on Oilseed Technologies and Utilization. T. H. Applewhite, ed. AOCS Press, Champaign, IL, 1992.

57. Rokey, G. J., Plattner, B., and Souza, E. M. Feed extrusion process description. R. Bras. Zootec. 39:510, 2010.

58. Alam, M. S., Kaur, J., Khaira, H., and Gupta, K. Extrusion and extruded products: Changes in quality attributes as affected by extrusion process parameters: A review. Crit. Rev. Food Sci. 56:445, 2016.

59. do Carmo, C. S., Varela, P., Poudroux, C., Dessev, T., Myhrer, K., Rieder, A., Zobel, H., Sahlstrom, S., and Knutsen, S. H. The impact of extrusion parameters on physicochemical, nutritional and sensorial properties of expanded snacks from pea and oat fractions. LWT-Food Sci. Technol. DOI: doi.org/10.1016/j.lwt.2019.108252. 2019.

60. Koksel, F., and Masatcioglu, M. T. Physical properties of puffed yellow pea snacks produced by nitrogen gas assisted extrusion cooking. LWT-Food Sci. Technol. 93:592, 2018.

61. Beck, S. M., Knoerzer, K., Foerster, M., Mayo, S., Philipp, C., and Arcot, J. Low moisture extrusion of pea protein and pea fibre forti- 
fied rice starch blends. J. Food Eng. 231:61, 2018.

62. Masatcioglu, M. T., and Koksel, F. Functional and thermal properties of yellow pea and red lentil extrudates produced by nitrogen gas injection assisted extrusion cooking. J. Sci. Food Agric. 99:6796, 2019.

63. Shoaib, A., Sahar, A., Sameen, A., Saleem, A., and Tahir, A. T. Use of pea and rice protein isolates as source of meat extenders in the development of chicken nuggets. J. Food Process. Pres. DOI: doi. org/10.1111/jfpp.13763. 2018.

64. Lusas, E. W., and Riaz, M. N. Soy protein products-processing and use. J. Nutr. 125:573, 1995.

65. Wang, N., Bhirud, P. R., and Tyler, R. T. Extrusion texturization of air-classified pea protein. J. Food Sci. 64:509, 1999.

66. Samard, S., and Ryu, G. H. A comparison of physicochemical characteristics, texture, and structure of meat analogue and meats. J. Sci. Food Agric. 99:2708, 2019.

67. Osen, R., Toelstede, S., Eisner, P., and Schweiggert-Weisz, U. Effect of high moisture extrusion cooking on protein-protein interactions of pea (Pisum sativum L.) protein isolates. Int. J. Food Sci. Technol. 50:1390, 2015.

68. Smetana, S., Pernutz, C., Toepfl, S., Heinz, V., and Van Campenhout, L. High-moisture extrusion with insect and soy protein concentrates: Cutting properties of meat analogues under insect content and barrel temperature variations. J. Insects Food Feed 5:29, 2019.

69. Kumar, P., Chatli, M. K., Mehta, N., Singh, P., Malav, O. P., and Verma, A. K. Meat analogues: Health promising sustainable meat substitutes. Crit. Rev. Food Sci. 57:923, 2017.

70. Allied Market Research. Global meat substitute market expected to reach $\$ 8.1$ billion by 2026. Published online at www.alliedmarketresearch.com/press-release/global-meat-substitute-market.html. Allied Market Research, Portland, OR, 2019.

71. The Good Food Institute. Profiles of U.S. early adopter consumer segments (updated). Published online at www.gfi.org/images/uploads/2020/01/Jan-2020-US-PBCM-Early-Adopter-Profiles-FINAL-REPORT-V2-changes-saved.pdf. GFI, Washington, DC, 2020.

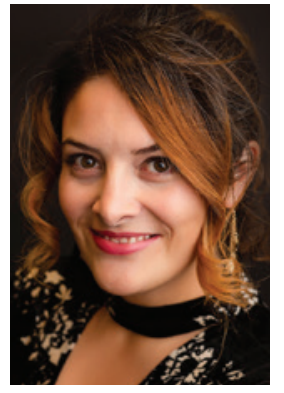

Serap Vatansever, Ph.D., is currently a postdoctoral research associate in the Dairy and Food Science Department at South Dakota State University, Brookings. Serap received her doctoral degree in the cereal science program at North Dakota State University, Fargo, in 2020. She focused on enhancing the utilization of pulse ingredients in the food system through flavor modification using supercritical carbon dioxide extraction during her doctoral program. She also has gained experience in pulse ingredient functionalities and their food applications, sensory evaluation of foods, food fermentation, food microbiology and biotechnology, other food processing technologies, and applied statistics over five years. Serap concluded her B.S. and M.S. degrees in the Department of Food Engineering at Pamukkale University in Turkey. She was also an exchange student for a year in the Department of Food and Nutrition at the University of Helsinki, Finland, during her undergraduate program. Serap has published several peer-reviewed journal articles, is currently preparing a book chapter, and has presented technical presentations globally. Serap is an active member of the Cereals \& Grains Association, the Institute of Food Technologists, and the Society of Sensory Professionals.

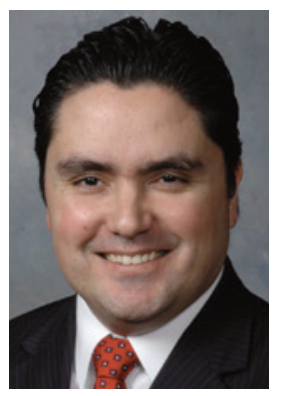

Mehmet Tulbek, Ph.D., is the director of the AGT Foods Research \& Development Centre in Saskatoon, Canada. Mehmet has more than 20 years of experience in cereal, pulse, and oilseed processing, technology, and utilization technologies. Mehmet concluded his B.S. degree in agricultural engineering with an emphasis in food science and technology at Ankara University, his M.S. degree in food engineering at Istanbul Technical University in Turkey, and his Ph.D. degree in cereal science at North Dakota State University, Fargo. Before joining AGT Foods, Mehmet worked at the Northern Crops Institute as technical director and crop quality specialist and led the development of $\mathrm{NCl}$ pulse, oilseed, and specialty crop technical, educational, and international outreach programs. Mehmet is the author of several journal articles, book chapters, and proceedings and has presented technical presentations globally. Mehmet is a member of the Cereals \& Grains Association, AOCS, IFT, CNS, and AAFCO.

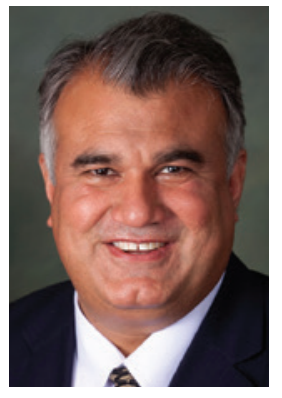

Mian N. Riaz, Ph.D., is the holder of a professorship in the Food Diversity Food Science and Technology Department at Texas A\&M University, College Station. He joined Texas A\&M University 27 years ago after completing his Ph.D. degree in food science from the University of Maine at Orono. His first academic appointment was in 1992 at the Texas A\&M University, Food Protein R\&D Center, where he was put in charge of the Food and Feed Extrusion program and went on to become the head of the Extrusion program. Mian has published 7 books and 25 chapters in different books. Currently, he teaches a course on Religious and Ethnic Food at Texas A\&M University. He successfully brought a $\$ 5$ million endowment to the Food Science Department for the Food Diversity program. 